\title{
The Knights-Errant of the Culture War
}

\section{Alex Priou}

Nearly every column written in the so-called culture war shares an assumption, that the war is not over, that the thing the culture warrior endeavors to save-be it liberal education, the soul of America, or even Western Civilization itself-is not already lost. This assumption is, of course, fair. The study of man and politics has yet to attain the precision of a diagnostic medical science. So there's no shame in still fighting, in spilling sweat for what's noble and good. But the very thing these culture warriors seek to defend, liberal education, requires, in David Bolotin's words, "a questioning of all inherited assumptions, including the most fundamental assumptions of one's political society," and "at least an openness to the possibility that they are wholly or partly false." Questioning the assumptions of the culture war thus belongs among the duties to which every culture warrior is called. What if our political life really has decayed beyond the point of saving? Bolotin considers this dark possibility; in so doing, he shows the intrepid among us that another way lies open and, indeed, always has.

In making his case, Bolotin draws on both Plato's Republic and his experience as a tutor at St. John's College. The Republic lays before us the possibility that, in Bolotin's words, "the political community is the greatest obstacle to the education of a philosopher" and thus to liberal education generally. That this claim held true not just in the days of Socrates' Athens, but holds true still today, is evident to Bolotin from his experience, which leads him to conclude that, when it comes to texts "critical of our contemporary beliefs and practices," "there is no discussion of these matters in class. In other words, we read the books, but we never entertain the possibility that what they say is true. Which is to say that we don't really read the books."

\footnotetext{
Alex Priou is a Teaching Assistant Professor in the Herbst Program for Engineering, Ethics, and Society at the University of Colorado Boulder and author of Becoming Socrates: Political Philosophy in Plato's Parmenides (University of Rochester Press, 2018). He is a graduate of the University of Connecticut, St. John's College, and Tulane University.
} 
Of course, Bolotin's experience is, like all experience, necessarily partial. But partial experience is especially revealing when the part experienced is the peak, or at least quite high. And where else would one expect our shared assumptions to be questioned but at St. John's College, where the Great Books form the whole of the curriculum and the manner of instruction is so free?

To judge by Bolotin's experience, however, students have eschewed questioning such conventional assumptions as human equality, and the equality of the sexes in particular, when the texts considered provide that opportunity. This is true, he says, of every seminar he has taught and of all those taught by others, of which he is aware, since he joined the faculty of the College. That was in 1974.

Bolotin offers a clear-sighted diagnosis of a possible cause of this state of affairs. The popular legitimacy and promotion of pleasure-seeking as a way of life has left many with the feeling that their lives are empty. When seeking "an escape from the unsatisfying pursuit of pleasure," “our new moralists" adopt an "egalitarian zeal." Accordingly, when an individual in pursuit of the higher ends of freedom, of free speech and inquiry, questions the assumptions of another in pursuit of those lower ends, a new sort of culture warrior emerges, one who would ennoble his pleasure-seeking by fighting for equality at the expense of freedom's higher ends. These other culture warriors thereby attain a sense of purpose, finding meaning in a movement that strives to secure for their progeny a life of pleasure-seeking that is ever freer from judgment. For that, it must also be free from questioning.

Of course, such an attempt at ennoblement is absurd, in that it subordinates the high to the low. We are told to praise those who denounce praise and blame, to honor those who defend our right to debase ourselves. Let's be frank, though: the situation is really much worse. Inasmuch as questioning is strictly forbidden, our self-debasement is not so much a right as it is a duty.

How are we to respond to this state of affairs? Fighting is one option. But Bolotin closes his remarks, made during a panel discussion at the College, by appealing to those in the audience who were drawn there out of discontent with the political situation so described, those who might harbor the hope that they could "learn what virtue and the good life truly are" from the Program. He advises such students as might be receptive to his criticisms "to discuss these doubts, to the extent possible, both in and out of class," that is, to engage in private conversations with similarly discontented friends and teachers. More 
fundamentally, he advises them not to rely on the political community for intellectual support but "to respect the power of your minds to help guide you to a better life, a power that may be much greater than you imagine.” His purpose, therefore, is not to reform the political community so much as to provoke individual reflection.

Bolotin's diagnosis of the political circumstances, as well as his understanding of Platonic political philosophy, temper his expectations of what writing and speaking can accomplish against prevailing political trends. The power of speech has never been great, but it is especially weak when it comes up against trends that are deeply rooted in the character of one's regime and the centuries-long project of modernity and modern liberalism. And it is fundamentally weak, when it encounters such a necessary and intractable obstacle as the political community.

Our culture warriors perhaps hope that the fracturing of the modern project offers opportunities of cultural restoration that would have been unavailable just a generation or two ago. They may well be right. But such political hopes-to save the soul of America and Western civilization-risk reducing us to our conventions and so deprecating the power of the individual mind. That is, at least, how some students might take it.

Alternatively, Bolotin reminds us that, even should we slide further into darkness than any of us presently fears, there will always remain the power of the human being to reflect rationally and meaningfully on his own good. He points both to the necessary closedness of the political community and to the always possible openness of the individual. This reminder, I think, should not be mistaken for a rejection of politics. (Bolotin does, after all, address his community as a whole.) The private life of philosophy, pursued alone or with friends, should never be chosen out of the bitter resignation characteristic of Adeimantus. But neither should one's political aspirations be pursued with Glaucon's unrealistic zeal. It's in this that the special merit of Bolotin's reminder lies. Though it may moderate our ambition, it may likewise ease our despair. Properly understood, it should temper our expectations while also stiffening our resolve. 